\title{
Philosophical and anthropological grounds of teaching of humanities for oil and gas engineering specialists
}

\author{
D. M. Skalska \\ Ivano-Frankivsk National Technical University of Oil and Gas \\ Corresponding author. E-mail: lilya.matiishun@gmail.com \\ Paper received 19.11.18; Accepted for publication 24.11.18.
}

\section{https://doi.org/10.31174/SEND-HS2018-185VI31-06}

\begin{abstract}
The article demonstrates anthropological discussion over basis of teaching humanities. It also contains analysis of origins and modern state of the notion of a human being and his/her artistic potential. The necessity of improving humanitarian schooling of future Oil and Gas Engineering specialists is proved.

Keywords: Philosophical anthropology, "humanocentrism" of the world, aesthetic culture, humanization of the education, Oil and Gas Engineering.
\end{abstract}

Introduction. Neoteric theories and methods of teaching humanity disciplines in technical Universities deserve more attention and are worth of future development. Especially in times of informationally-technical society among educating future owners of Master's degree of European level.

Short overview of related works. The sources for this investigation are: academic works and researching experiments in field of philosophy of education, science and methodology of scientific cognition.

The ones that have a direct modernization touch and the changes in education of humanities sciences, for technicians are stressed on.

The core interest of this investigation is philosophically-anthropological cognition, its history, ideas and priorities. The following have been grounded in practical philosophies of Hryhoriy Skowoorda (Ukrainian phylosophist, writer, public speaker); Pamfley Yurkevych (professor of Philosophy); "heart philosophy" of the alumni of Kyiv-Mohyla Academy; personality concepts of Nikolai Berdyaev (Russian politician and religious philosopher).

Additionally, it is vital to mention the importance of achievements in teaching field of such authors as Zyazyun, Soldatenko, Semenog, Ivanov, and especially Andryushchenko, Dzvivchuk, Vonkova.Aim: to involve the best practices for the formation of professional education and encouraging research of the philosophical and anthropological fundamentals of training specialists in the field of mining, oil and gas extraction, and oil and gas business.

Aim: to involve the best practices for the formation of professional education and encouraging research of the philosophical and anthropological fundamentals of training specialists in the field of mining, oil and gas extraction, and oil and gas business.

Basis and methods. In the scientific work of any specialist takes part the unstoppable absorption of certain knowledge: understanding of the scientific picture of the world; the true meaning of the essence of wonders and processes; the ability to apply general and specific methods during the study.

"In the $20^{\text {th }}$ century many important changes in the methodology of cognition took place.

Certainty of the fact that the objective structure of understanding, formed in culture, does not allow development of a unified approach to the solution of complex variety of problems. Especially the ones that are concern- ing the activities of the systems of the highest level of organization: the person, society, culture. The ideas of theoretical cybernetics, system analysis, synergetic, seeking to connect different approaches between different sciences in a single system of methods have come to a discussion"[1 p. 414]. This is an exact reason why the scientist should have the profound philosophical knowledge.

The informational epoch generates new challenges: the global problems of society are deepened, such as: the fundamental uncertainty of the essence of information, the interaction of technology and nature, the interaction of technology, information and rights.

All together brings up a necessity of introducing a person to a computerized environment, comprehending the prospects and consequences of the creation of artificial intelligence.

Scientists seek for ideas to overcome the anthropological crisis. This leads to the creation of newest practices and methods. "In humanistic management as an anthropocentric matrix, a total approach to the study of man as a socio-cultural entity is used, the emphasis is on the formation of a society based on the ideals of justice, solidarity, social consensus, on the basis of which is the anthropological mode: meaning the anthropological transformations of the social state, sustainable social development, overcome of the gap between Ukraine and other highly developed countries "[2 sec. 21].

The priorities should point at the obedience of the quality of education and science with European standards. At the same time the teaching of highly skilled professionals for Ukraine and for the world. For instance, IvanoFrankivsk National Technical University of Oil and Gas is the only high-tech oil and gas profile in Ukraine. Its ultimate goal is to ensure the energy security of our country. Scientists of the university have developed the program "Scientific and organizational principles for increasing the production of domestic oil and gas and diversifying the supply of energy resources to enhance the energy security of the state."

Worth mentioning the fact of constantly ongoing work about optimizing the structure of the institution in order to provide high quality training for future oil and gas engineering specialists at IFNTUOG. Innovations of this university include the establishment of teaching methodological associations according to different specialties, which include employers, students, experts from many depart- 
ments. Also the development of methodological guidelines and recommendations for the preparation of new curricula on the basis of the most up-to-date educational programs. Also, the organization of the educational process constantly undergoes improvements in accordance with the orders of employers; modern tools of information technology and progressive methods of intensifying the educational process are used.

Domestic Ukrainian anthropological thought can be considered as the origin of the pedagogical and educational reception which was begun in the practical philosophy of G. Skovoroda, the cardiosophy P. Yurkevich, moral-value "philosophy of the heart" of the followers of the Kyiv-Mohyla Academy. Existential anthropology was formed within the framework of modern Kyiv school and the philosophically-anthropological school. It focuses on the fundamental research of existential dimensions of human existence through the reflection of the worldview and its theoretical transformations. The founder of this school was V. I. Shynkaruk. He pointed to the existences of human being, "faith", "hope", "love", as ones which lead the person to its authenticity, humanity. Social anthropology and pedagogy in the field of domestic scientific thought have shown its philosophical maturity and the ability to collaborate with the evolutionary processes of Western anthropological consciousness.

Nevertheless, all previously mentioned investigations share disadvantage: the predominance of socialization in the understanding of man; the exaggeration of social role functions in life and communication; the absence of existential, artistic and aesthetic aura; the neglect of biological and mental components as the necessary factors for individual and social coexistence for further implementation of pedagogical and educational actions.

Similar situation was happening in Ukraine during a certain period of post-Soviet times. However, the "anthropological Renaissance" began in the 60's of the twentieth century and managed to attract several generations of philosophers. The term "philosophical anthropology," is often associated with dilemmas and conflicts. Thus, the well-known historian of philosophical anthropology, V. Bruning, refers to it all possible philosophical doctrines of a man, regardless of their occurrence in the historical and temporal space and the core dominant problem: either it is ontological, theoretical-cognitive, logical-methodological or, indeed, anthropological. However, he singles out the philosophical tradition as purely anthropological one, in which a person becomes the original substance, the main object of philosophizing. He refers it to such a tradition as personalism, some varieties of neoclassicism, existentialism, and the school of "philosophical anthropology", initiated by M. Scheler. Whilst modern phenomenologist E. Fink points out somewhat different interpretation for the term of "anthropology". In his opinion, all existing science is "rooted" in the anthropological interest of man to himself, and therefore the subject of all sciences / man / finds in anthropology a genuine understanding of himself, that is, a being capable of understanding.

The area of philosophical and anthropological research spreads in the discussions of the classical, non-classical, post-classical and new-classical traditions; about premodern, modern and postmodern as cultural landmarks in the understanding of man and ones boundaries. Basing on the anthropological doctrine of L. Feuerbach, perceiving the natural and scientific achievements of anthropology as one of the sections of positive science, having received an ideological impulse from German romanticism and the late "philosophy of life", incorporating the influences of psychoanalysis, Z. Freud, K. Jung, the phenomenology of E. Husserl and fundamental ontology M. Heidegger, constructed the philosophical anthropology of the XX century, which became w a paradigm of philosophical thinking and a subject field for the evolution of any upcoming theories.

First of all, the philosophy of man is to be determined as one of the components of the humanization of philosophical thinking; and philosophical anthropology, as a form of social consciousness, having its subject and place in the system of scientific knowledge. The overwhelming majority of Modern thinkers avoid declaring the existence of an objective "reality-as-it-is," and willingly point to "reality-from a certain point of view." They even underline the belief that science is essentially no different from art / P. Fayerabend /, and as a result of "poeticism" of culture, its cultural artifacts can be paralleled and compared only with each other, rather than with the world of reality / R. Rorty /. It is known that in critical cases of scientific practice some scholars / M. Bor, A. Einstein, V. Heisenberg / turned to aesthetic reasoning, and A. Poincare convinced that the main guarantee for good mathematics was not logical factors, but aesthetic abilities.

In a highly structured technogenic society, where artificial intelligence is requested to replace the idealization of "beautiful", humanities reorient in the context of virtuality and modeling / virtuality and modelability /, signaling the possible appearance of other forms of anthropology, - the "negative" one. Total aestheticization / creation of something artificial / leads to the fact that aesthetic competence compensates loss of moral standards, often pursuing only economic or political strategies. Under such conditions, when the boundaries between art and life are whipped out, do scientists question the positive compromises positively or the complex of negatives? / As integral and Philosophy can not be reduced to a single paradigm, as well as pedagogical skill avoids single authorship or authoritarianism.

Philosophical and anthropological dimensions of humanitarian disciplines became possible on the basis of overcoming the gap between scientism and humanism, on strengthening the interrelations between analytical philosophy, the historical school in the philosophy of science, neofreydizm, structuralism, hermeneutics in the formation of an unconventional image of philosophical thinking, and the desire to create new schools of pedagogical anthropology [3].

Teaching humanitarian disciplines in technical universities is one of the factors of the anthropological process as a fundamental training of specialists in the oil and gas industry. Some human-science issues have always been present in the research "What is a man?", varying from pre-Socratic and Socrates to postmodernists and technocrats. In the Western European scientific space, already 200 years ago, based on the teachings of I. Kant, for who believed education was a transcendental expression the practical forms of morality, the status of fundamental epistemological discipline was consolidated in pedagogy. 
Through the ethical and aesthetic worldview, attempts were made to conclude a special style of thinking, a specific method of comprehension of reality, which could be called anthropological. Therefore, a significant contribution to the development of the topic of humanitarian education for all levels of training oil and gas personnel are the following problems: the definition of man as a holistic image in a certain type of culture; Definition of the concepts of "man, humanity, individual, personality, person, personality" in their correlation and interpretation; disclosure of nature and the essence of man as a combination of "artificial and natural", "material and physical and sociocultural," as a moral value and ethical and aesthetic knowledge.

Theorists focus their attention on subject of philosophical anthropology, the authenticity of the anthropological idea, the anthropological theme as the dominant, anthropological principles and categories, author's approaches, the presence of anthropological renaissance, the stages of anthropological turn. Therefore, the core of analysis reveals the "human-dimensionality" of the world. The educational parameters of this "human-dimensionality" are established in several directions: one of them - the comparison of the phenomenon under investigation with other entities and phenomena; the other is the self-identification of its own unique nature.

The study of features of human-dimensionality, as one of the ways implies an understanding of the relationship between man and nature / cosmos / society, God, himself. Disclosure of internal intentions is associated with, biological, emotional, moral, spiritual, social being. Both approaches are complementary, provide the necessity for emotion-building on a new basis, especially if it relates to the skill of the teacher in the technical university.

Human-science conflicts arising from situations of difficult political periods, historical, cultural, and economic fragmentations have not omitted the Ukrainian society. Characteristically, the general turn of Western European culture to the problem of man was concentrated on the anthologizing of philosophical knowledge. Eventually, the growth of this process is closely connected to the change in methodological paradigms, which is confirmed by nowadays scientific works. The most popular ones are comparisons of such major stashes: classics, post-classics / non-classics / premodern, modern and postmodern.

Worth mentioning the fact that the classical methodology was based on ideological principles that "dictated" their laws of understanding of the world. For example, the "world" category was decisive and fundamental, and was associated with a self-sufficient and perfect reality. According to the principles of classics, subordination to stereotypes, established rules and norms was associated with the transcendental absolute. In the classical methodology, there is always a division: a person - the subject; and the opposite self-sufficient world- the object, where the main course is the concentration on the ideal, perfection, truth. For both classical science and classical art, maximalism is the prerogative, which in various forms of imperialism fights for the "purity of principles", perfection, rejecting everything that has the features of unfinished, instantaneous, mysterious. Elegance and proficiency, as one of the conditions of classical activity, anticipates the advantage of a form over the extraction of con- tent, which eventually leads to a certain degeneration, alienation from the reality, the arrival of locked up systems and structures.

Consequently, any dogmatization of requirements is a ground for both vanishing and the appearance of the alternative ideas. The experience of classical methodologies has produced non-classical innovations which influenced the resumption of anthropocentrism and led to a new understanding of human philosophy, its meaning, tenacity and purpose in the universe. Non-classical supervisor of the new methodology was the "anthropological turn" as a fundamental field change, subject, arsenal of tools of critical reflection because of new perceptions of a person becoming dominant in the philosophical consciousness of the 21 st century. Unlike the classical guidelines of rationalism, the prominent place is taken by the direct and unconscious experience, a unique phenomenon of a person's feelings and perception. The mentioned ones ground a unique original integrity in a human being. Man appears as infinite, rooted in the world substance. The methodological principles are not originated from refined abstractions, but from human-like being, specific in each situation. Thus, the person himself serves the criterion and purpose of methodological actions. Recently, these ideas have been activated by studies of the Kyiv Philosophical and Anthropological School, in particular the work of the "philosophers of the sixties". In their philosophical reflections on the past and the present, not only the deep understanding of the modern man is present, but also the foundations for solving urgent affairs of domestic anthropological science, the implementation of philosophical practice, and solutions to the problems in the conditions of the global crisis are laid.

A nonclassical path leads not to the opposition of the object and subject, but to the comparison of the inner world and external reality. Of course, "absolutizing of subjective" leads to responsibility for dealing with new dilemmas of human nature, such as: self-sufficiency, selfidentification, self-estimation. In any case, what happens in the traditional methodology, confrontation arena of various approaches, points of view, hypotheses, concepts, testifies major expanse of post-classics, which requires detailed research and substantiation of its perspectives. In the history of philosophy, the Renaissance periods are well known, when in pursuit of high ideas and good intentions, the one that made it possible to understand the most important thing - himself, was lost. The study of the human phenomenon is complicated because of the fact that each individual has a constant need to solve life problems that arise all the time and are always urgent. Could there be a huge number of teachings about a person in a single universe? the wise men and scientists spent considerable potential of knowledge and intelligence to find an answer to this question, and yet the premonition of the apocalypse, the "collapse of civilization" or "the end of history," especially on the verge of millennia, is constantly chased by humanity.

Results. One of the fruitful directions of the development of philosophical anthropology was its ability to be a peculiar key for understanding the diverse aspects and levels of aesthetic culture. Understanding the artistic potentials of a man, his aesthetic feelings, needs is closely linked with the anthropological principle, which combines 
the unconditionally biological preconditions of sensuality and its socio-historical characteristics.

In terms of ontological, psychological, activity, the axiological principle of anthropology allows us to reveal a number of features of the formation of aesthetic consciousness. According to the anthropological approach, a man in his development passes the stage of the combination of an impersonal level of perception with an individual-personality, which is due to all the cultural and historical features of one's life. The combination of sensory perception, as a generic characteristic of man, and the general comprehension of meaning, as a form of its spiritual, cultural activity, leads to clarification of the specifics of artistic language, language of art. Distant, at first glance, observations about mechanisms of sensory perception are extremely necessary for understanding of the combination of anthropocultural and that what is embodied in natural human sensuality. The consideration of anthropological prerequisites in the analysis of aesthetic experience or artistic practice makes it possible to evaluate phylogenetic and ontogenetic processes in the formation of sensory culture.

On the other hand, exactly because of the aesthetic attitude of a person to the world we can judge ones ability to realize its generic nature. Aesthetic development of a person does not only cover ones ability to have imagination, practice, understanding, but also gives the opportunity to navigate in temporal and spatial dimensions, to adequately build up the behavior, to plan their activities.
Thus, we see that anthropological and aesthetic are organically combined in the philosophical understanding of man, they keep its integrity, preserve uniqueness, which is essentially important in the education of specialists in the oil and gas complex as an engineering elite, part of the European intelligentsia.

Conclusions. An extremely important and determining factor in raising the level of higher education is the improvement of the pedagogical skills of participants in the educational process and the optimization of the conditions under which this process is carried on.

1. Pedagogical work of teachers of higher educational institutions is defined as a special form of humanism, highly skilled mental activity of an artistic character. 2. Teaching humanitarian disciplines for oil and gas specialists is aimed at training, education, development of creativity, the formation of their professional knowledge, skills and the formation of their active life position. 3 . The philosophic-anthropological maturity of the teacher can be gained through constant work in increasing one's level of proffecionalism, gradual transition to active forms of learning, the combination of traditional approaches with problem-searching. 4. The complex of organizational, methodological, methodological, moralpsychological, ethical, aesthetic, and social problems of the higher education system that arise in the course of advanced training of specialists in Ukraine should be based on philosophical-anthropological traditions and innovations.

\section{ЛIТЕРАТУРА}

1. Андрущенко В. П., Дзвінчук Д. І. Основи сучасної філософії освіти: Навчальний посібник. - К. - Ів.Франківськ: Місто НВ, 2009. - 456 с.

2. Воронкова В.Г., Андрюкайтене, Регіна, Максименюк М.Ю., Нікітенко В.О. Формування концепції гуманістичного менеджменту та іiі вплив на розвиток людського потенціалу в умовах глобалізації та євроінтеграції // Гуманітарний вісник Запорізької державної інженерної академії: збірник наукових праць,

вип. № 65/ Під. ред. В.Г. Воронкової; Запоріз. держ. інж. акад. - Запоріжжя: ЗДІА, 2016.- 292 с.

3. Скальська Д.М. Філософські чинники науки у підготовці фахівців нафтогазового комплексу. // Актуальні проблеми розвитку освіти і науки в умовах глобалізації. Матеріали II всеукраїнської наукової конференції. 28-29 жовтня 2016 р., м. Дніпро. Частина II. / Наук. ред. О.Ю.Висоцький. - Дніпро: Роял Принт, 2016. - с. 40-42.

\section{REFERENCES}

1. Andrushhenko V. P., Dzvinchuk D. I. Osnovy` suchasnoyi filosofiyi osvity`: Navchal`ny`j posibny`k. - K. - Iv.Frankivs`k: Misto NV, 2009. - 456 s.

2. Voronkova V.G., Andryukajtene, Regina, Maksy`menyuk M.Yu., Nikitenko V.O. Formuvannya koncepciyi gumanisty`chnogo menedzhmentu ta yiyi vply`v na rozvy`tok lyuds`kogo potencialu v umovax globalizaciyi ta yevrointegraciyi // Gumanitarny`j visny`k Zaporiz koyi derzhavnoyi inzhenernoyi akademiyi: zbirny`k naukovy`x pracz`, vy`p. \#

65/ Pid. red. V.G. Voronkovoyi; Zaporiz. derzh. inzh. akad. Zaporizhzhya: ZDIA, 2016.- 292 s.

3. Skal`s`ka D.M. Filosofs`ki chy`nny`ky` nauky` u pidgotovci faxivciv naftogazovogo kompleksu. // Aktual'ni problemy` rozvy`tku osvity` i nauky` v umovax globalizaciyi. Materialy` II vseukrayins koyi naukovoyi konferenciyi. 28-29 zhovtnya 2016 r., m. Dnipro. Chasty`na II. / Nauk. red. O.Yu.Vy`socz`ky`j. - Dnipro: Royal Pry`nt, 2016. - s. 40-42. 